\title{
ELECTROCHEMICAL CHARACTERISTICS OF AUSTENITIC STAINLESS STEEL IN MIXED CHLORIDE - MOLVBDATE SOLUTIONS
}

The effect of molybdate addition to chloride solutions on resistance of AISI 316Ti stainless steel to pitting corrosion was studied. Potentiodynamic polarization tests were performed in $1 \mathrm{M}$ and $0.1 \mathrm{M}$ chloride acidified solutions with various additions of sodium molybdate at room temperature. The presented results compare the effect of molybdate anions on quality of passive film (expressed by the pitting potential) in both chloride solutions. The pitting potential increases with the increase of inhibitor concentration. The inhibitive effect of molybdate ions is stronger in chloride solution of lower aggressiveness (0.1M).

Keywords: AISI 316Ti steel, molybdate inhibitor, pitting corrosion, pitting potential, potentiodynamic polarization.

\section{Introduction}

Generally stainless steels are not corrosion resistant in aggressive chloride environments and they are prone to local corrosion, namely pitting [1 - 4]. This form of corrosion is very destructive and dangerous because of the possibility of material perforation. Addition of an inhibitor to corrosion environment is one of the possible ways to improve their resistance to pitting. Some inhibitors prevent nucleation of pits others promote repassivation or prevent the growth of stable pits. It is very difficult to find an inhibitor efficient in all the mentioned phases of the pitting process [1]. Stopping the stable pit growth is a very complex issue, and therefore the research of effective inhibitors points to the inhibition of the initiation phase of pitting [1 and 5].

Molybdate ions are considered by many authors [1, 5 - 9] an efficient oxidizing anodic inhibitor for pitting corrosion of stainless steels. The inhibitive effect of molybdate ions has been described both in neutral and acid chloride solutions [1, 5 - 9]. The primary step of their action is the adsorption on the metal surface which enables to prevent the breakdown of surface passive film [1 and 5].

Some authors [1 and 5] emphasize that inhibitive species are only effective above a certain concentration ratio of inhibitive to aggressive ions. This relationship in a simplified form has been described as follows:

$\log c_{A}=A+B \log c_{N}$ where $c_{A}$ is the concentration of the aggressive ions, $c_{N}$ is the concentration of the inhibitive (non-aggressive) ions and $A$ and $B$ are constants.

The authors [5] apply the ratio between concentration of molybdate ions and concentration of chloride ions 1:10 and they document positive effect of the inhibitor on the embryonic stages of pitting corrosion (metastable pitting) and on the value of the pitting potential as well.

Other authors $[6-7,10-12]$ present the inhibitive effect of various non-aggressive ions added to chloride solutions in a broad interval of concentration ratios (from 1: 250 to 1:1). The authors [7] studied corrosion behavior of 2205 duplex stainless steel and they pointed out that the pitting corrosion does not occur in $0.1 \mathrm{M}$ $\mathrm{NaCl}+0.1 \mathrm{M} \mathrm{MoO}_{4}^{2-}$ even at the temperature of $85^{\circ} \mathrm{C}$.

AISI 316Ti is Cr-Ni-Mo stainless austenitic steel stabilized by Ti. It is recommended for various industrial and biomedical applications. However, its resistance to pitting is not sufficient in chloride environments [3-4, $11-12]$. The presented paper focuses on the effect of molybdate ions on the pitting corrosion resistance of the above mentioned $\mathrm{Cr}-\mathrm{Ni}-\mathrm{Mo}$ stainless steel. Potentiodynamic polarization tests were carried out in $1 \mathrm{M}$ and $0.1 \mathrm{M}$ chloride acidified solutions $(0.9 \mathrm{M} \mathrm{NaCl}+0.1 \mathrm{M} \mathrm{HCl}$ and $0.09 \mathrm{M} \mathrm{NaCl}+0.01 \mathrm{M} \mathrm{HCl}$ respectively) in the absence and presence of sodium molybdate. The applied concentration ratios

\footnotetext{
* 'Viera Zatkalikova, ${ }^{1}$ Lenka Markovicova, ${ }^{2}$ Anna Wrobel-Knysak 
between molybdate and chloride ions were 1:10 and 1:20 for both chloride solutions.

\section{Experimental material and methods}

AISI 316Ti stainless steel with the chemical composition shown in Table 1 was used as an experimental material. The steel was purchased in sheet $(1500 \times 1200 \mathrm{~mm})$ of $1.5 \mathrm{~mm}$ thickness and its treatment (marked as 2B) was based on annealing and pickling after smoothing rolling [13].

Microstructure of the original material was observed by the optical metallographic microscope Neophot 32 in longitudinal section (Fig. 1).

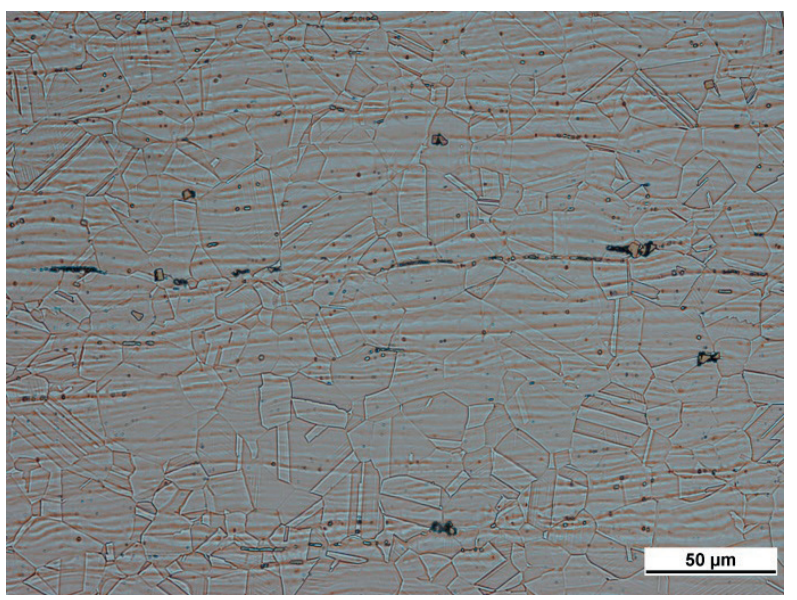

Fig. 1 Microstructure of AISI 316Ti stainless steel in longitudinal section (etch. $10 \mathrm{~cm}^{3} \mathrm{HNO}_{3}+20 \mathrm{~cm}^{3} \mathrm{H}_{3} \mathrm{PO}_{4}+30 \mathrm{~cm}^{3}$ glycerin, for 5 minutes)

Microstructure is typical austenitic. It is created by polyedric austenitic grains with observable twins (Fig. 1), which could be created by annealing or by rolling. Parallel lines arose by the rolling during the technologic process. Observed microstructure contains numerous carbides. (Mo, Ti)C carbides are of cubic shape, (Mo, $\mathrm{Cr})_{23} \mathrm{C}_{6}$ carbides are concentrated into lines [14].

Potentiodynamic polarization tests were carried out in a three electrode cell, polarization curves were obtained by the EC-LAB SOFT software. Potential between the sample and the electrolyte had been settled for 10 minutes before the polarization. Scan range was $-0.3 \mathrm{~V}-0.9 \mathrm{~V}$ vs the open circuit potential and the scan rate was $1 \mathrm{mV} / \mathrm{s}$. The surface of working electrode AISI 316Ti of $1 \mathrm{~cm}^{2}$ area was not mechanically treated, only rinsed with diethyl ether before measurement. The saturated calomel electrode
(SCE) was applied as the reference electrode and platinum foil as a counter electrode. All experiments were carried out at ambient temperature of $20 \pm 3^{\circ} \mathrm{C}$.

Potentiodynamic experiments were performed in $1 \mathrm{M} \mathrm{Cl}$ acidified solution $(0.9 \mathrm{M} \mathrm{NaCl}+0.1 \mathrm{M} \mathrm{HCl})$ with $0.05 \mathrm{M}$ and $0.1 \mathrm{M}$ additions of $\mathrm{Na}_{2} \mathrm{MoO}_{4}$, and in $0.1 \mathrm{M} \mathrm{Cl}$ acidified solution $(0.09 \mathrm{M} \mathrm{NaCl}+0.01 \mathrm{M} \mathrm{HCl})$ with $0.005 \mathrm{M}$ and $0.01 \mathrm{M}$ additions of $\mathrm{Na}_{2} \mathrm{MoO}_{4}$. It means that the applied concentration ratios between inhibitive (molybdate) and aggressive (chloride) ions were 1:10 and 1:20 for both chloride solutions. At least five experiment repeats were carried out for all specimens.

Pitted surfaces of working electrode AISI 316Ti after potentiodynamic polarization tests were observed by the optical microscope (NIKON AZ 100).

\section{Results and discussion}

Potentiodynamic polarization curves enable determination of the pitting potential $\left(E_{p}\right)$, which is an important electrochemical characteristic of the resistance to pitting. When the potential reaches this critical value, current density suddenly increases, denoting the breakdown of the passive film and the beginning of stable pit growth. The shift of $E_{p}$ to more positive values on the polarization curve means the rise of resistance to pitting [1 - 3].

Potentiodynamic polarization curves of AISI 316Ti stainless steel in $1 \mathrm{M} \mathrm{Cl}$ solution in the absence and presence of sodium molybdate ( $0.05 \mathrm{M}$ and $0.1 \mathrm{M}$ additions) are shown in Fig. 2.

As we can see, the higher inhibitor concentration $(0.1 \mathrm{M})$ caused the extension of the passive region to higher positive potential values and therefore the pitting potential $E_{p 3}$ is markedly higher than the pitting potential in the absence of molybdate inhibitor $E_{p l}$. The addition of $0.05 \mathrm{M} \mathrm{Na}_{2} \mathrm{MoO}_{4}$ into $1 \mathrm{M}$ chloride solution (curve 2 in Fig. 2) caused only very slight extension of passive region to higher potential values. Due to the unusual course of this polarization curve at which a moderate gradual increase in current density already in a passive state is observed, it was difficult to identify the precise point of depassivation. According to authors [2 and 3] if a reached current density equals $0.05 \mathrm{~mA} . \mathrm{cm}^{-2}$, it is considered the clear depassivation and an initiation of the stable growing pit. Taking into account the above mentioned condition the pitting potential $E_{p 2}$ (Fig. 2) was located.

All three polarization curves in Fig. 3 have a very similar shape with low current density in the passive state. The pitting potentials increase with the rise of inhibitor concentration in $0.1 \mathrm{M}$ chloride solution. It is clear that even lower molybdate

Chemical composition of experimental material

Table 1

\begin{tabular}{|l|l|l|l|l|l|l|l|l|l|l|l|}
\hline $\begin{array}{l}\text { Content } \\
\text { of element } \\
\text { [wt.\%] }\end{array}$ & $\mathrm{Cr}$ & $\mathrm{Ni}$ & $\mathrm{Mo}$ & $\mathrm{Mn}$ & $\mathrm{N}$ & $\mathrm{Ti}$ & $\mathrm{C}$ & $\mathrm{Si}$ & $\mathrm{P}$ & $\mathrm{S}$ & $\mathrm{Fe}$ \\
\cline { 2 - 11 } & 16.5 & 10.6 & 2.12 & 1.69 & 0.012 & 0.41 & 0.04 & 0.43 & 0.026 & 0.002 & balance \\
\hline
\end{tabular}




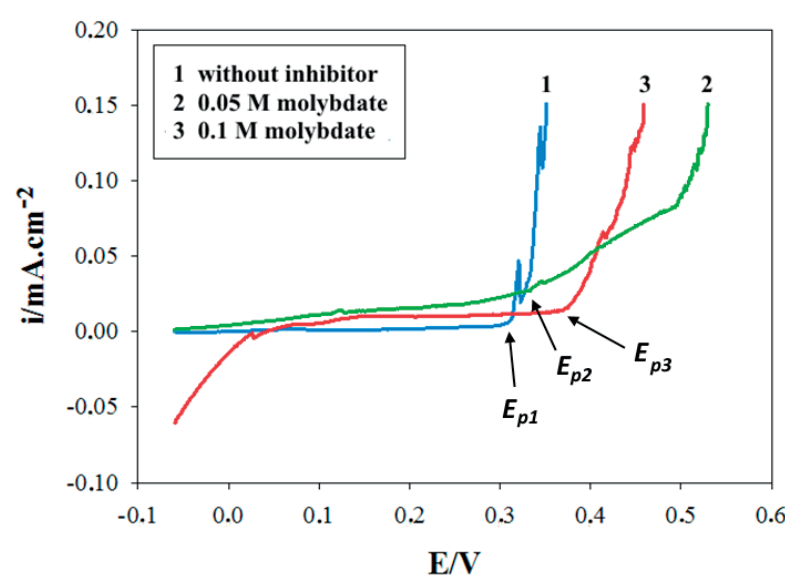

Fig. 2 Anodic potentiodynamic curves for AISI 316Ti working electrode in $1 \mathrm{M} \mathrm{Cl}$ solution

concentration $\left(E_{p 2}\right)$ ensured a noticeable shift of the pitting potential in positive direction.

In $1 \mathrm{M}$ chloride solution the passive current density is higher in the presence of inhibitor than in its absence (Fig. 2). The passivity in $0.1 \mathrm{M}$ chloride solution seems to be more stable and is slightly supported by the presence of inhibitor.

$\mathrm{MoO}_{4}^{2-}$ ion has markedly higher radius $\left(\mathrm{MoO}_{4}^{2-}\right.$ radius $=$ $242.10^{-12} \mathrm{~m}, \mathrm{Cl}^{-}$radius $\left.=181.10^{-12} \mathrm{~m}\right)$ and therefore higher specific adsorption than aggressive $\mathrm{Cl}$ ion [5]. Molybdate inhibitive effect is based on strengthening of surface passive film by its adsorption and subsequent reduction $\left(\mathrm{Mo}^{6+}\right.$ is reduced to $\mathrm{Mo}^{4+}, \mathrm{MoO}_{2}$ is formed) as follows [6]:

$\mathrm{MoM}_{4}^{2-}+4 \mathrm{H}^{+}+2 e^{-} \Rightarrow \mathrm{MoO}_{2}+2 \mathrm{H}_{2} \mathrm{O}$

Due to the binding of $\mathrm{H}^{+}$with oxygen, the reaction (2) also contributes to reduction of local acidity and therefore to formation of less aggressive solution.

However $\mathrm{MoO}_{4}^{2-}$ ability to adsorb on the steel surface in sufficient amount may depend not only on the concentration ratio of inhibitive to aggressive ions but on the level of chloride solution aggressiveness (chloride concentration and acidity) as well. The same concentration ratio inhibitive to aggressive ions $(0.05$, that is 1:20) causes the different increase of pitting potential in $0.1 \mathrm{M}$ and $1 \mathrm{M} \mathrm{Cl}^{-}$solutions. This phenomenon is clearly visible in comparison of the pitting potentials $\left(E_{p}\right)$ in dependence on concentration ratios (Fig. 4).

Figure 5 shows pitted surfaces of working electrode AISI $316 \mathrm{Ti}$ after potentiodynamic polarization tests in $1 \mathrm{M}$ chloride solution in the absence and presence of sodium molybdate (observed by optical microscope).

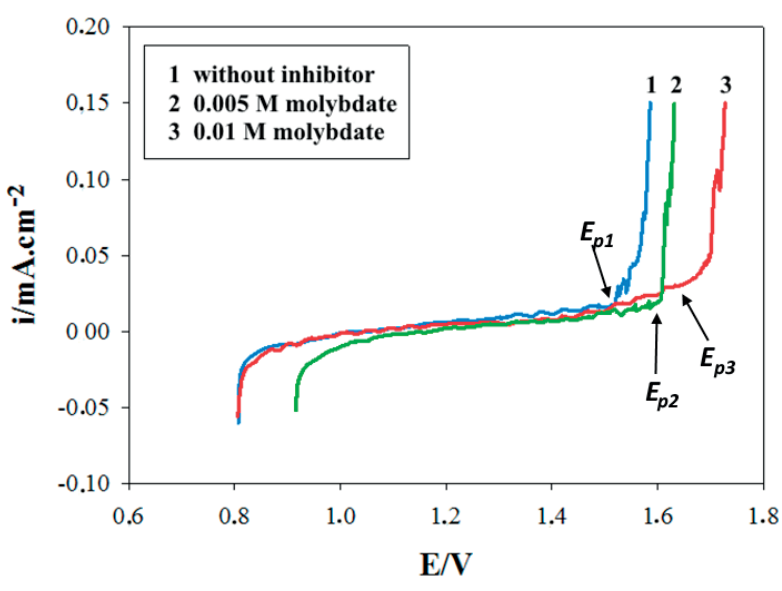

Fig. 3 Anodic potentiodynamic curves for AISI 316Ti working electrode in $0.1 \mathrm{M} \mathrm{Cl}$ solution

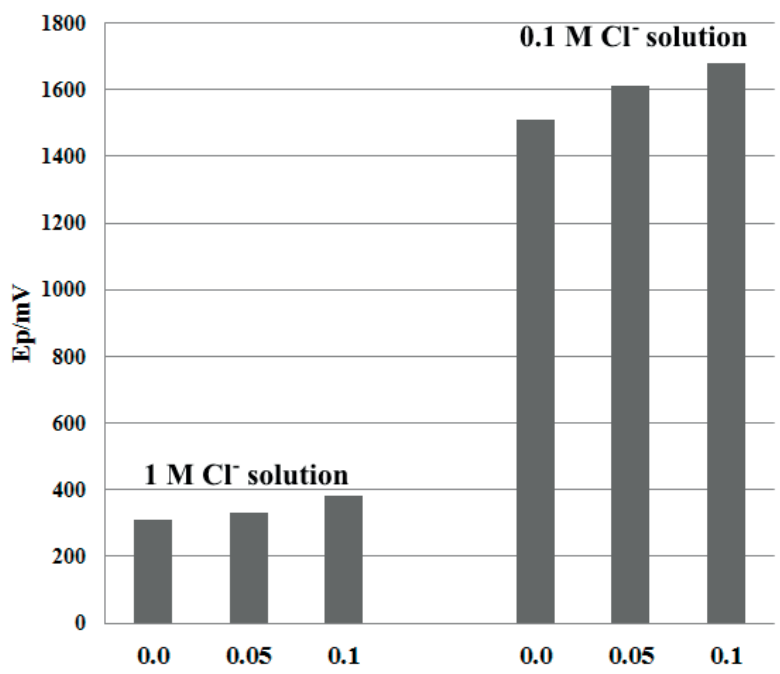

Fig. 4 Comparison of the pitting potentials $\left(E_{p}\right)$ in dependence on concentration ratio $\mathrm{MoO}_{4}^{2-} / \mathrm{Cl}(0.0 ; 0.05 ; 0.1)$ in $0.1 \mathrm{M}$ and $1 \mathrm{M}$ chloride solutions

The observed pitted surfaces are very similar. The inhibitor used did not significantly affect the size or the shape of pits.

The pitting of working electrode AISI 316Ti, after potentiodynamic polarization tests in $0.1 \mathrm{M}$ chloride solution in the absence and presence of sodium molybdate, was not observable (under the same conditions).

\section{Conclusions}

Based on the results of performed potentiodynamic polarization tests the following can be concluded:

- Addition of the inhibitor in both chloride environments widened the passivity region of AISI 316Ti stainless steel and increased the pitting potential in positive direction. 


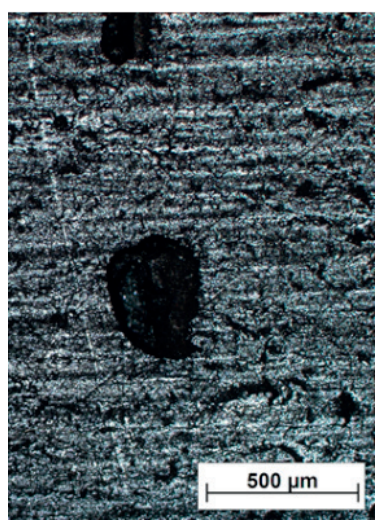

a)

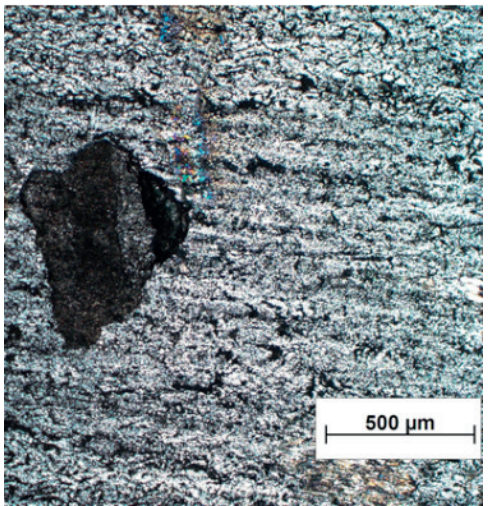

b)

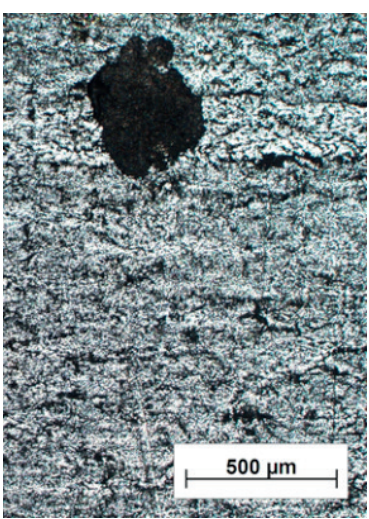

c)

Fig. 5 Pitted surfaces of working electrode AISI 316Ti after potentiodynamic polarization tests in $1 \mathrm{M}$ chloride solution: (a) without inhibitor, (b) with $0.05 \mathrm{M} \mathrm{Na}_{2} \mathrm{MoO}_{4}$ (c) with $0.1 \mathrm{M} \mathrm{Na}_{2} \mathrm{MoO}_{4}$

- Due to high passive current density in $1 \mathrm{M}$ chloride solution with lower concentration of inhibitor (concentration ratio of inhibitive to aggressive ions $\mathrm{Cl} 1: 20$ ), as clearly positive result can be considered an increase of the pitting potential at a higher concentration of inhibitor (ratio 1:10). In this case molybdate inhibitor can be recommended for an increasing of AISI 316Ti resistance to pitting.

- In $0.1 \mathrm{M}$ chloride solution a lower concentration of inhibitor (concentration ratio of inhibitive to aggressive ions $\mathrm{Cl}^{-1} 1: 20$ ) was sufficient for the significant shift of the pitting potential towards positive values. The difference between the pitting potential using lower and higher concentrations is lower than between absence and lower inhibitor concentration. On the basis of the above mentioned facts, a lower concentration of molybdate inhibitor seems to be more favorable (taking into account the economic and environmental point of view) for increasing of the AISI 316Ti resistance to pitting in this solution.

\section{Acknowledgments}

The research is supported by VEGA No. 1/0683/15.

\section{References}

[1] SZKLARSKA-SMIALOWSKA, Z.: Pitting and Crevice Corrosion, Houston: Nace, 2005.

[2] UHRICIK, M., ORAVCOVA, M., PALCEK, P., SAPIETA, M., CHALUPOVA, M.: The Stress Detection and the Fatigue Lifetime of Stainless Steel AISI 316L during Three-Point Bending Cyclic Loading. EAN 2016: $54^{\text {th }}$ Intern. Conference on Experimental Stress Analysis, Zapadoceska univerzita: Plzen, 2016.

[3] MAZUR, M., ULEWICZ, R., NOVY, F., SZATANIAK, P.: The Structure and Mechanical Properties of Domex 700 MC Steel, Communications - Scientific Letters of the University of Zilina, 15 (4), 2013.

[4] TRSKO, L., BOKUVKA, O., PALCEK, P., NOVY, F., MIKOVA, K.: Fatigue Resistance of C30 Structural Steel. Communications - Scientific Letters of the University of Zilina, 17 (3), 2015.

[5] ILEVBARE, G. O., BURSTEIN, G. T.: The Inhibition of Pitting Corrosion of Stainless Steels by Chromate and Molybdate Ions. Corrosion Science, vol. 45, 2003.

[6] REFAEY, S. A. M., ABD EL-REHIM, S. S., TAHA, F., SALEH, M. B., AHMED, R. A.: Inhibition of Chloride Localized Corrosion of Mild Steel by $\mathrm{PO}_{4}^{3-}, \mathrm{CrO}_{4}^{2-}, \mathrm{MoO}_{4}^{2-}$, and $\mathrm{NO}_{2}^{-}$Anions. Applied Surface Science, vol. 158, 2000.

[7] EGHBALI, F., MOAYED, M. H., DAVOODI, A., EBRAHIMI, N.: Critical Pitting Temperature (CPT) Assessment of 2205 Duplex Stinless Steel in $0.1 \mathrm{M} \mathrm{NaCl}$ at Various Molybdate Concentrations. Corrosion Science, vol. 53, 2011.

[8] TOBLER, W. J., VIRTANEN, S.: Effect of Mo Species on Metastable Pitting of Fe18Cr Alloys - A Current Transient Analysis. Corrosion Science, vol. 45, 2003.

[9] ALENTEJANO, C. R., AOKI, I. V.: Localized Corrosion Inhibition of 304 Stainless Steel in Pure Water by Oxyanions Tungstate and Molybdate. Electrochim. Acta, vol. 49, 2004. 


\section{coMMNICOIIONS}

[11] EL DAHAN, H. A.: Pitting Corrosion Inhibition of 316 Stainless Steel in Phosphoric Acid-Chloride Solutions. J. of Materials Science, vol. 34, 1999.

[12] ZUO, Y., WANG, H., ZHAO, J., XIONG, J.: The Effects of some Anions on Metastable Pitting of 316L Stainless Steel, Corrosion Science, vol. 44, 13-24, 2002.

[13] http://www.italinox.sk/ (10. 2. 2017).

[14] PARDo, A., MERINO, M. C., COY, A. E., VIEJO, F., CARbOnERAS, M., ARrABAL, R.: Influence of Ti, C and N Concentration on the Intergranular Corrosion Behavior of AISI 316Ti and 321 Stainless Steels. Acta Materialia, vol. 55, 2007. 